\title{
Integrated Nutrient Management for Enhanced Yield, Nutrients Uptake and their Use Efficiency in Rice under Intensive Rice-Wheat Cropping System
}

\author{
Sunil Kumar', Bholanath Saha ${ }^{2 *}$, Sushanta Saha ${ }^{3}$, Anupam Das ${ }^{1}$, \\ Parthendu Poddar ${ }^{4}$ and Manikant Prabhakar
}

${ }^{1}$ Department of Soil Science and Agricultural Chemistry, Bihar Agricultural College, Bihar

Agricultural University, Sabour, Bhagalpur, Bihar - 813 210, India

${ }^{2}$ Department of Soil Science, Dr. Kalam Agricultural College, Bihar Agricultural University,

Kishanganj, Bihar - 855 107, India

${ }^{3}$ Directorate of Research, Bidhan Chandra Krishi Viswavidyalaya, Kalyani,

Nadia, West Bengal-741 235, India

${ }^{4}$ Department of Agronomy, Uttar Banga Krishi Viswavidyalaya, Pundibari,

Coochbehar, West Bengal-736 165, India

${ }^{5}$ Department of Soil Science, Nalanda College of Horticulture, Bihar Agricultural University,

Noorsarai, Nalanda, Bihar - 803 113, India

*Corresponding author

\section{A B S T R A C T}

\begin{tabular}{|l|}
\hline K ey w or d s \\
FYM, Green \\
manure, Grain \\
yield, INM, \\
Nutrient use \\
efficiency, Nutrient \\
uptake, Rice. \\
\hline Article Info \\
\hline $\begin{array}{l}\text { Accepted: } \\
\text { 17 September } 2017 \\
\text { Available Online: } \\
\text { 10 October } 2017\end{array}$ \\
\hline
\end{tabular}

A field experiment was conducted during kharif season at Rajendra Agricultural University, Pusa to assess the impact of conjoint use of organics and chemical fertilizers on yield, nutrients uptake and use efficiency in rice. Results revealed that among the organics, green manuring by dhaincha (GM) produced highest grain yield $\left(39.90 \mathrm{q} \mathrm{ha}^{-1}\right)$ followed by farm yard manure (39.26 q ha $\left.\mathrm{qu}^{-1}\right)$, urd $\left(34.70 \mathrm{q} \mathrm{ha}^{-1}\right)$ and straw $\left(31.64 \mathrm{q} \mathrm{ha}^{-1}\right)$. Increasing levels of inorganic fertilizers also increased the rice grain and straw yield with the maximum grain $\left(44.94 \mathrm{q} \mathrm{ha}^{-1}\right)$ and straw $\left(61.05 \mathrm{q} \mathrm{ha}^{-1}\right)$ yield was observed in $100 \%$ recommended NPK treatment. Among all the treatments, highest grain yield $\left(53.24 \mathrm{q} \mathrm{ha}^{-1}\right)$ and uptake of major nutrients i.e. $\mathrm{N}\left(112.27 \mathrm{~kg} \mathrm{ha}^{-1}\right), \mathrm{P}\left(22.23 \mathrm{~kg} \mathrm{ha}^{-1}\right)$ and $\mathrm{K}(144.90 \mathrm{~kg}$ $\mathrm{ha}^{-1}$ ) in rice were observed under combined application of $100 \%$ NPK + GM. Besides this, the fertilizer use efficiency (FUE) in terms of apparent recovery for $\mathrm{N}, \mathrm{P}$ and $\mathrm{K}$ was found maximum in the treatment replacing $50 \%$ of $\mathrm{N}$ through GM $+50 \%$ NPK. Thus, INM approach is not only a reliable way for obtaining fairly high productivity with increased FUE but also an alternative practice towards sustainable agriculture.

\section{Introduction}

Among the cereals, rice and wheat are the world's most important staple food crops and are generally grown in sequence in the South Asia occupying an area of about 13.5 million ha of prime agricultural land in Bangladesh, India, Nepal, and Pakistan, with another 12 million ha in China (Ladha et al., 2000). In India alone, the system occupies about 10.0 million ha in the Indo-Gangetic plains (IGP) mostly located in UP (4.8 m ha), Punjab (1.5 $\mathrm{m} \mathrm{ha}$ ), Bihar (1.6 m ha), MP (1.3 m ha) and Haryana (0.5 m ha) (Singh et al., 1994; 
Modgal et al., 1995; Ladha et al., 2003; Das et al., 2014) and provides food security for 400 million of people (Ladha et al., 2000). Looking at the actual scenario in the northern alluvial belt, it seems that available resources and input use may account for higher productivity in Punjab and poor yields in Bihar (Modgal et al., 1995). These variations in productivity may be due to variations in the agro-ecological conditions, degree of water control, levels of inputs used and farmers' skill. This system is primarily dependent on inorganic fertilizers only. Deficit in availability of fertilizer nutrients is one problem and declining tendency in rice-wheat productivity due to continuous use of only inorganic fertilizers in the system is the other (Ladha et al., 2003; Rahman et al., 2009). In order to make the soil well supplied with all the plant nutrients in the readily available form and to maintain good soil health, it is necessary to use organic manures in conjunction with inorganic fertilizers to obtain optimum yields (Ramalakshmi et al., 2012).

Currently it is estimated that only $30-50 \%$ of applied nitrogen fertilizers and $45 \%$ of phosphorus fertilizers are used for crops (Ladha et al., 2005; Ghosh et al., 2015). However, the efficiency of nutrient use may be enhanced by the combined use of organic and inorganic fertilizers (Kumar et al., 2014). The rice-wheat cropping system needs higher inputs and the declining trends in system's productivity due to depletion of organic matter in the soil, which results disturbance in soil aggregation, soil productivity and soil health (Abrol and Gill, 1994; Modgal et al., 1995; Patro et al., 2011) need to be taken care of prudently. Since the farmers of the region are resource poor, therefore, there is a need for complete or partial substitution of inorganic fertilizers, by locally available organic sources for sustaining rice production (Acharya and Mandal, 2010; Brahmachari et al., 2011; Yadav et al., 2013). Individual and integrated application of cyanobacterial biofertilizer and GM with chemical fertilizer improved the soil health and production of rice crop and it resulted in a savings of $50 \mathrm{~kg}$ $\mathrm{N} \mathrm{ha}^{-1}$ (Jha et al., 2013).

Integrated use of these organic manures along with chemical fertilizers enhances yield of rice upto 20-30\% and other physiological characteristics as well as better nutrient uptake (Mehdi et al., 2011; Mohanty et al., 2013; Yadav et al., 2013). Long term studies being carried out at several locations in India indicated that application of all the needy nutrients through chemical fertilizers have deleterious effect on soil health leading to unsustainable yields (Jaga, 2013). Therefore, there is a need to improve nutrient supply system in terms of integrated nutrient management involving the use of chemical fertilizers in conjunction with organic manures coupled with input through biological processes (Prasad et al., 1995; Aulakh, 2010). Moreover, application of imbalanced nutrients could lead to declining nutrient-use efficiency making fertilizer consumption uneconomical and adversely affecting the atmosphere (Aulakh and Adhya, 2005) and groundwater quality (Aulakh et al., 2009) causing health hazards and climate change. Under such a condition, there is need to explore the possibilities of using the expanding native sources of plant nutrient. The organic sources of nutrients like dhaincha, rice straw and green legumes (Dixit and Gupta, 2000) and organic manure such as FYM (Kumari et al., 2010) are gaining global importance for rice (Oryza sativa L.). In this context, the present study was undertaken to study the effect of integrated supply of inorganic fertilizers along with some organic sources of nutrients on yield, nutrients uptake by rice and nutrient use efficiency under intensively cultivated rice-wheat cropping systems. 


\section{Materials and Methods}

\section{Site description}

The field experiment was conducted with test crop rice in rice-wheat copping system on an Inceptisols at North Chhawania of Rajendra Agricultural University, Pusa, Bihar, India

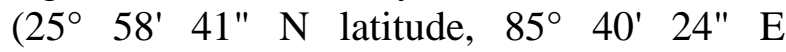
longitude and $52.4 \mathrm{~m}$ above mean sea level). The climate is hot, humid subtropics with an average annual rainfall of approximately 1380 $\mathrm{mm}$ and mean annual minimum and maximum temperatures of 13.5 and $38.2^{\circ} \mathrm{C}$, respectively. The soil is hyperthermic (Aeric Haplaquept) according to US Soil Taxonomy, Soil Survey Staff (2003) and silty clay to clay in texture. The $\mathrm{pH}$ of the soil at the start of experiment was neutral $(\mathrm{pH} 7.8)$ in reaction with sand, silt, and clay values of 515.0, 273.0 , and $212.0 \mathrm{~g} \mathrm{~kg}^{-1}$, respectively. The oxidizable organic $\mathrm{C}$, available $\mathrm{N}, \mathrm{P}$ and $\mathrm{K}$ content of the soil $(0-0.2 \mathrm{~m})$ are $5.1 \mathrm{~g} \mathrm{~kg}^{-1}$, $200.32 \mathrm{~kg} \mathrm{ha}^{-1}, 14.46 \mathrm{~kg} \mathrm{ha}^{-1}$ and $96.18 \mathrm{~kg}$ $\mathrm{ha}^{-1}$, respectively. The bulk density and cation exchange capacity values of the initial soil were $1.35 \mathrm{Mg} \mathrm{m}^{-3}$ and $31.0 \mathrm{Cmol}(\mathrm{p}+) \mathrm{kg}^{-1}$, respectively.

\section{Description of field experiment}

Rice (Oryza sativa L.) was grown under irrigated condition following the standard package of practices. The popularly grown rice cultivar Gautam was used for the experiment. Seedlings were raised for 25 days @ $50 \mathrm{~g} \mathrm{seed} / \mathrm{m}^{2}$ in seedbed after seed treatment with bavistin @ $2 \mathrm{~g} / \mathrm{kg}$ seed followed by treatment with a salt solution for two minutes. Healthy seedlings were transplanted to the main field following $20 \mathrm{~cm}$ row to row spacing. The experimental plot was well drained and had uniform topography with assured tube well irrigation facility. The experiment was laid out in a split plot design with five main plot treatments and five subplot treatments in three replications. The organic sources of nutrients are used in main plots, while inorganic sources of nutrients were used in sub plot treatments. The details of main plot treatments were $\mathrm{M}_{1}$ - green manure [dhaincha (Sesbania rostrata)], $\mathrm{M}_{2}-$ green legume [urd (Vigna mungo)], $\mathrm{M}_{3}-$ FYM@10 t ha $a^{-1}, M_{4}$ - straw @ $5 \mathrm{tha}^{-1}$ and $\mathrm{M}_{5}$ - weedy fallow, whereas, the details of sub-plot treatments were $\mathrm{S}_{1}-$ Control, $\mathrm{S}_{2}-$ $50 \%$ PK, $S_{3}-50 \%$ NPK, $S_{4}-100 \%$ PK and $\mathrm{S}_{5}-100 \%$ NPK. The recommended dose of NPK was $120 \mathrm{~kg} \mathrm{~N}, 60 \mathrm{~kg} \mathrm{P}_{2} \mathrm{O}_{5}$ and $40 \mathrm{~kg}$ $\mathrm{K}_{2} \mathrm{O}$ per hectare. The NPK concentration in these organic treatments and their contribution after incorporation in soils are presented in Table 1.

\section{Analytical procedure}

Grain and straw yield of rice and wheat were recorded from a harvest area of $10 \mathrm{~m}^{2}$. Plant samples were first washed with running tap water followed by washing with $0.01 \mathrm{~N} \mathrm{HCl}$ and finally with double distilled water. After that, plant samples were dried in a hot air oven at $50^{\circ} \mathrm{C}$ for 48 hours till the constant weight was achieved. After drying, the samples were ground to fine powder by using stainless steel grinder for further analysis. Total $\mathrm{N}$ content of the plant samples as well as organic materials were analyzed by Kjeldahl method using Kel-Plus analyzer (Pelican Equipments, Chennai, India), while total $\mathrm{P}$ and $\mathrm{K}$ content of the plant samples and organic materials were analyzed in aqueous extracts prepared after wet-digestion with a di-acid mixture of $\mathrm{HNO}_{3}$ and $\mathrm{HClO}_{4}$ (9:4 ratio) using using UV-Visible spectrophotometer (Systronics 118) and Flame photometer (Systronics 128), respectively (Jackson, 1973).

\section{Apparent nutrient recovery for NPK}

Apparent recovery efficiency is often used as an indicator of the potential for nutrient loss from the cropping system and to access the 
efficiency of management practices. Apparent recovery of each of the nutrients viz. $\mathrm{N}, \mathrm{P}$ and $\mathrm{K}$ were estimated by the following formula (after Doberman, 2007):

Apparent nutrient recovery $($ ANR $)=\left(\mathrm{U}-\mathrm{U}_{0}\right) / \mathrm{F}$

Where, $U=$ total nutrient uptake in aboveground crop biomass with nutrient applied; $\mathrm{U}_{0}=$ nutrient uptake in aboveground crop biomass with no nutrient applied; $\mathrm{F}=$ amount of nutrient applied.

\section{Statistical analysis}

The analysis of variance (ANOVA) of the measured parameters was performed by windows based Statistical Package namely SPSS (ver. 9.3) and the least significant difference (LSD) test was applied to evaluate the significance of the differences between the variables and treatments.

\section{Results and Discussion}

\section{Grain and straw yield}

The grain yield of rice varied from 21.41 to $53.24 \mathrm{q} \mathrm{ha}^{-1}$ with a mean value of $34.74 \mathrm{q}$ ha 1 as influenced by different treatment combinations (Table 2). The grain yield of rice was significantly influenced by different organic sources. Averaged over fertilizer treatments, the maximum yield (39.90 q ha $\left.{ }^{-1}\right)$ was recorded in dhaincha (GM) treatment and was at par with FYM treatment (39.26 q ha $\left.{ }^{-1}\right)$ but was better than urd (GL) (34.70 q ha ${ }^{-1}$ ), straw (31.64 q ha ${ }^{-1}$ ) and weedy fallow (28.22 $\left.\mathrm{q} \mathrm{ha}{ }^{-1}\right)$. Thus, the effect of organic manures on grain yield of rice were in the order: dhaincha $(\mathrm{GM})=\mathrm{FYM}>$ urd $>$ straw $>$ weedy fallow . The impact of chemical fertilizers, averaged over organics, was found significant in improving the grain yield of rice from 27.56 to $44.94 \mathrm{q} \mathrm{ha}^{-1}$ in control and $100 \%$ NPK, respectively. The grain yield in $100 \%$ NPK treatment (44.94 $\mathrm{q} \mathrm{ha}^{-1}$ ) was followed by $50 \%$ NPK (38.04 q ha-1), 100\% PK (32.63 q ha-1), $50 \%$ PK (30.54 q ha ${ }^{-1}$ ) and control (27.56 q $\left.\mathrm{ha}^{-1}\right)$. The differences between $100 \%$ PK and $50 \%$ PK were also statistically significant. The effect of NPK with respect to grain yield of rice can be shown by following order: $100 \%$ NPK $>50 \%$ NPK > 100\% PK > 50\% $\mathrm{PK}>$ control. Grain and straw yield increased significantly with increasing level of NPK fertilizers and the increase in grain yield over control was 52.8, 98.8 and $119.3 \%$ with the application of 50, 100 and $150 \%$ NPK, respectively. This was also corroborated with the findings of Kumar et al., (2011). The interaction effects of organic and inorganic fertilizers were found to be statistically nonsignificant. The effectiveness of combined use of dhaincha (GM) or FYM with inorganic fertilizers on grain yield of rice was best when $100 \%$ NPK was used in conjunction with dhaincha or FYM.

The straw yield of rice varied from 31.25 to $69.85 \mathrm{q} \mathrm{ha}^{-1}$ as influenced by different treatment combinations (Table 2). The main effect of organic manures was found significant, which improved the straw yield from $37.91 \mathrm{q} \mathrm{ha}^{-1}$ (weedy fallow) to $51.71 \mathrm{q}$ $\mathrm{ha}^{-1}(\mathrm{GM})$. The GM (51.71 q ha ${ }^{-1}$ ) and FYM $\left(49.83 \mathrm{q} \mathrm{ha}^{-1}\right)$ were at par and were better than GL (44.45 q ha ${ }^{-1}$ ), straw (42.83 q ha ${ }^{-1}$ ) and weedy fallow (37.91 q ha-1). The response of organic sources with regard to straw yield of rice can be shown by following order: dhaincha $(\mathrm{GM})=\mathrm{FYM}>$ urd $(\mathrm{GL})>$ straw $>$ weedy fallow. Incorporation of FYM and other organics to NPK fertilizers significantly increased grain and straw yield of rice, which is corroborated with the findings of the previous studies reported by Kumar et al., (2011); Patro et al., (2011); Sharma and Banik (2012); and Mohanty et al., (2013). Integrated use of organics with mineral fertiliser improves the grain and straw yield (Li et al., 2010; Srinivasarao et al., 2014; 
Mitran et al., 2015) and facilitates the translocation of nutrients to the economic part of the crop (Yang et al., 2004), thus increasing use efficiency of the applied nutrients (Ghosh et al., 2015). Application of inorganic fertilizers, averaged over organic sources, significantly increased the straw yield over the control. The maximum yield (61.05 q ha ${ }^{-1}$ ) was recorded with $100 \%$ NPK treatment which was followed by $50 \%$ NPK (48.79 $\mathrm{q} \mathrm{ha}^{-1}$ ), 100\%PK (42.29 q ha ${ }^{-1}$ ), 50\% PK (39.27 q ha ${ }^{-1}$ ) and control (35.27 q ha-1). The interaction effect between organic and inorganic fertilizers was found to be significant. The maximum straw yield $(69.85$ $\mathrm{q} \mathrm{ha}{ }^{-1}$ ) of rice was recorded with GM and $100 \%$ NPK combination; while, the minimum was (31.25 q ha ${ }^{-1}$ ) recorded with weedy fallow and control treatment combination.

The effects of GM and FYM treatments in combination with inorganic fertilizers on straw yield of rice were at par with all the levels of inorganic fertilizers (except under $50 \%$ PK and 50\% NPK). Except under 50\% NPK, similar results were also found with urd (GL) and straw.

However, minimum straw yield was recorded in weedy fallow treatment irrespective of organic or inorganic sources of nutrients and their combinations, because these plots were devoid of nutrient addition and suffering from severe crop-weed competition for nutrients.

The higher grain and straw yield in plot supplied with $100 \%$ NPK (through chemical fertilizers) along with GM and FYM could be due to higher availability of nutrient and modifying soil environment for better retention of nutrient and water during the critical crop growth stages (Dass et al., 2009). Integrated use of nutrient sources accelerates translocation of nutrients to the economic part of the crops, hence resulted higher grain yield with albeit no significance in straw yield (Das et al., 2014). Our study also showed coherence with the facts, that application of green manures Sesbania and Crotalaria at $10.0 \mathrm{t} \mathrm{ha}^{-1}$ along with NPK to rice compared to no green manure application significantly increased grain yield of rice by 1.6 and $1.1 \mathrm{t}$ $\mathrm{ha}^{-1}$, respectively. In case of $50 \% \mathrm{PK}$ and $100 \%$ PK treatments, grain and straw yield in rice were found very low than $50 \%$ NPK and $100 \%$ NPK treatments, respectively which might be due to sub-optimal dose of nutrients.

\section{Nutrient uptake}

\section{Nitrogen uptake by grain and straw}

A perusal of data presented in Table 3 entailed that $\mathrm{N}$ uptake by rice grain and straw varied from 18.82 to $66.65 \mathrm{~kg} \mathrm{ha}^{-1}$ and 15.01 to $45.65 \mathrm{~kg} \mathrm{ha}^{-1}$ due to different treatment combinations, respectively. Result indicated that the addition organic amendments have significant positive response on $\mathrm{N}$ uptake and the highest $\mathrm{N}$ uptake (averaged over fertilizer combinations) was recorded in GM treated plots $\left(42.48 \mathrm{~kg} \mathrm{ha}^{-1}\right.$ in grain and $32.65 \mathrm{~kg} \mathrm{ha}^{-1}$ in straw). The effect of GM (dhaincha) (42.48 $\left.+32.65 \mathrm{~kg} \mathrm{ha}^{-1}\right)$ and FYM $(41.21+30.87 \mathrm{~kg}$ $\mathrm{ha}^{-1}$ ) were also found statistically at par with respect to $\mathrm{N}$ uptake by rice crop.

Succulency and higher nitrogen content (low $\mathrm{C}: \mathrm{N}$ ratio) in green manures resulted in rapid decomposition and subsequently greater release of $\mathrm{N}$ during the crop growth period leading to higher $\mathrm{N}$ uptake by the crop as compared to FYM. In addition to that it has priming effects that facilitating various biological transformations in soil.

Inorganic fertilizer treatments, averaged over organics, exerted significant influence on $\mathrm{N}$ uptake both by rice grain and straw. Among the various levels of NPK fertilizers, the uptake value increased with increasing levels of fertilizers. The $\mathrm{N}$ uptake by grain was 
found in the order of: $100 \%$ NPK $(52.05 \mathrm{~kg}$ $\left.\mathrm{ha}^{-1}\right)>50 \%$ NPK $\left(41.69 \mathrm{~kg} \mathrm{ha}^{-1}\right)>100 \%$ PK $\left(29.35 \mathrm{~kg} \mathrm{ha}^{-1}\right)=50 \%$ PK $\left(27.96 \mathrm{~kg} \mathrm{ha}^{-1}\right)>$ control $\left(25.63 \mathrm{~kg} \mathrm{ha}^{-1}\right)$. Similar trend was also observed in $\mathrm{N}$ uptake by rice straw. Increased $\mathrm{N}$ uptake due to increasing levels of chemical fertilizers may be ascribed to the fact that rice plants grew better and accumulated more dry matter in NPK treated plots as compared to control leading to higher $\mathrm{N}$ uptake in comparison to control (Udayasoorian et al., 1997; Dass et al., 2009).

The interaction effect between organic and inorganic nutrient management treatments on removal of $\mathrm{N}$ by both grain and straw has found to be significant. Uptake of $\mathrm{N}$ in both the grain $\left(66.65 \mathrm{~kg} \mathrm{ha}^{-1}\right)$ and straw $(45.65 \mathrm{~kg}$ $\mathrm{ha}^{-1}$ ) with $100 \%$ NPK + GM had been found to be more effective over control as well as over weedy fallow combination (18.82 $\mathrm{kg} \mathrm{ha}^{-1}$ in grain and $15.01 \mathrm{~kg} \mathrm{ha}^{-1} \mathrm{~N}$ in straw).

Enhancement in $\mathrm{N}$ uptake by rice plants with nutrient sources especially GM and FYM supplemented with any level of inorganic fertilizers probably resulted in the availability of more amount of nutrients throughout the plant growth as compared to sole application of fertilizers, indicating better utilization of applied nutrients under the combined application of inorganic and organic source of plant nutrients (Dubey et al., 1997; Karmakar et al., 2011; Kumar et al., 2014).

\section{$P$ uptake grain and straw}

The perusal of data in Table 4 revealed that the $\mathrm{P}$ uptake by rice grain varied from 3.61 to $12.94 \mathrm{~kg} \mathrm{ha}^{-1}$ due to the influence of different organic and inorganic combinations. Under no fertilizer control, the uptake of $\mathrm{P}$ has ranged from 3.61 in weedy fallow to $6.16 \mathrm{~kg}$ $\mathrm{ha}^{-1}$ in GM (Dhaincha) exhibiting the influence of organics in increasing its uptake in the rice grains. The highest $\mathrm{P}$ uptake by rice grain was observed in $100 \% \mathrm{NPK}+\mathrm{GM}$ treatment $\left(12.94 \mathrm{~kg} \mathrm{ha}^{-1}\right)$. Similarly, the average $P$ uptake by rice grain significantly increased from 5.16 to $10.14 \mathrm{~kg} \mathrm{ha}^{-1}$ in control and $100 \%$ NPK levels, respectively. However, the average $\mathrm{P}$ uptake by rice grain varied from 5.27 to $8.85 \mathrm{~kg} \mathrm{ha}^{-1}$ because of incorporation of various organic sources. These results inferred that a general increase in P uptake seemed to be associated with the $P$ availability which happened due to the increasing levels of NPK application when soil is deficient in $\mathrm{P}$.

Besides this, it was apparent that $\mathrm{P}$ uptake by rice grain was found maximum at $100 \%$ NPK levels $\left(12.94 \mathrm{~kg} \mathrm{ha}^{-1}\right)$ followed by $50 \%$ NPK level $\left(9.78 \mathrm{~kg} \mathrm{ha}^{-1}\right)$ and lowest in control $\left(6.16 \mathrm{~kg} \mathrm{ha}^{-1}\right)$ under GM treatment. Further, it was also noticed that, among the organics, significantly higher $\mathrm{P}$ uptake by rice grain were observed in GM and FYM treatments than the others. So far P uptake by rice straw was concerned, the similar trend as in case of rice grain was observed. Phosphorus uptake by rice straw was found in the following order: dhaincha $\left(6.16 \mathrm{~kg} \mathrm{ha}^{-1}\right) \approx$ FYM $(5.81$ $\left.\mathrm{kg} \mathrm{ha}^{-1}\right)>\operatorname{urd}\left(4.92 \mathrm{~kg} \mathrm{ha}^{-1}\right)>$ straw $(4.52 \mathrm{~kg}$ $\left.\mathrm{ha}^{-1}\right)>$ weedy fallow (3.81 $\left.\mathrm{kg} \mathrm{ha}^{-1}\right)$. Phosphorus removal in rice grain was also found higher by about one and half times or even more than its uptake in straw, because of higher translocation efficacy of nutrient in grain (economic part) under integrated use of organic and inorganic nutrient sources ( $\mathrm{Li}$ et al., 2010).

Besides this, the results revealed that the increase in nutrient supply obviously induced better plant growth which might have improved the absorption of phosphorus from the soil. The present findings are also in conformity with the several earlier reports which revealed enhanced P-uptake by rice crop as a result of increased NPK supply (Patel et al., 1997; Kumar et al., 2011). 
Table.1 Biomass, dry matter, nutrient content and nutrients (NPK kg ha ${ }^{-1}$ ) added to soil by organics

\begin{tabular}{|c|c|c|c|c|c|c|c|c|}
\hline \multirow{2}{*}{$\begin{array}{l}\text { Organic } \\
\text { sources }\end{array}$} & \multirow{2}{*}{$\begin{array}{l}\text { Fresh } \\
\text { weight } \\
\left(\mathrm{t} \mathrm{ha}^{-1}\right)\end{array}$} & \multirow{2}{*}{$\begin{array}{c}\text { Dry weight } \\
\left(\mathrm{t} \mathrm{ha}^{-1}\right)\end{array}$} & \multicolumn{3}{|c|}{ Nutrients content } & \multicolumn{3}{|c|}{ Nutrients accumulation through organics } \\
\hline & & & $\mathrm{N}(\%)$ & $\mathrm{P}(\%)$ & $\mathrm{K}(\%)$ & $\mathrm{N}\left(\mathrm{kg} \mathrm{ha}^{-1}\right)$ & $\mathrm{P}\left(\mathrm{kg} \mathrm{ha}^{-1}\right)$ & $\mathrm{K}\left(\mathrm{kg} \mathrm{ha}^{-1}\right)$ \\
\hline $\begin{array}{l}\text { Dhaincha } \\
\text { (GM) }\end{array}$ & 10.36 & 2.95 & 2.19 & 0.42 & 1.73 & 64.60 & 12.39 & 51.03 \\
\hline Urd (GL) & 6.48 & 2.27 & 2.33 & 0.58 & 1.17 & 52.89 & 13.16 & 26.56 \\
\hline FYM & 10.00 & 6.50 & 1.26 & 0.29 & 0.68 & 81.90 & 18.85 & 44.20 \\
\hline Wheat straw & 5.00 & 4.45 & 0.54 & 0.08 & 1.08 & 24.03 & 3.60 & 48.06 \\
\hline $\begin{array}{l}\text { Weedy } \\
\text { fallow }\end{array}$ & 5.40 & 2.10 & 0.39 & 0.18 & 0.50 & 8.19 & 3.78 & 10.50 \\
\hline
\end{tabular}

Table.2 Influence of organic and inorganic fertilizers on grain and straw yield of rice in rice-wheat cropping system

\begin{tabular}{|c|c|c|c|c|c|c|c|c|c|c|c|c|}
\hline \multirow[b]{2}{*}{ Treatments } & \multicolumn{6}{|c|}{ Grain yield $\left(\mathrm{q} \mathrm{ha}^{-1}\right)$} & \multicolumn{6}{|c|}{ Straw yield $\left(\mathrm{q} \mathrm{ha}^{-1}\right)$} \\
\hline & \multicolumn{6}{|c|}{ Organic sources } & \multicolumn{6}{|c|}{ Organic sources } \\
\hline Inorganic fertilizer levels & Dhaincha (GM) & Urd (GL) & FYM & Straw & Weedy fallow & Mean & Dhaincha (GM) & Urd (GL) & FYM & Straw & Weedy fallow & Mean \\
\hline Control & 31.36 & 28.73 & 30.6 & 25.72 & 21.41 & 27.56 & 38.98 & 34.72 & 37.02 & 34.37 & 31.25 & 35.27 \\
\hline $50 \% \mathrm{PK}$ & 34.29 & 31.92 & 33.58 & 27.29 & 25.6 & 30.54 & 43.03 & 39.97 & 40.72 & 38.84 & 33.76 & 39.26 \\
\hline $50 \%$ NPK & 44.07 & 36.76 & 43.48 & 34.66 & 30.86 & 37.97 & 59.02 & 46.44 & 56.02 & 43.22 & 39.26 & 48.79 \\
\hline $100 \% \mathrm{PK}$ & 36.53 & 32.81 & 35.67 & 29.89 & 28.27 & 32.63 & 47.66 & 41.81 & 46.71 & 40.19 & 35.06 & 42.29 \\
\hline $100 \%$ NPK & 53.24 & 43.29 & 52.57 & 40.65 & 34.94 & 44.94 & 69.85 & 59.34 & 68.31 & 57.50 & 50.23 & 61.05 \\
\hline Mean & 39.90 & 34.70 & 39.26 & 31.64 & 28.22 & 34.74 & 51.71 & 44.45 & 49.83 & 42.83 & 37.91 & 45.35 \\
\hline \multicolumn{2}{|l|}{ Sources } & \multicolumn{2}{|c|}{ SEm } & \multicolumn{3}{|c|}{$\mathrm{CD}(p=0.05)$} & \multicolumn{3}{|c|}{ SEm } & \multicolumn{3}{|c|}{$\mathrm{CD}(p=0.05)$} \\
\hline \multicolumn{2}{|c|}{ Organic manures (m) } & \multicolumn{2}{|c|}{0.89} & \multicolumn{3}{|c|}{2.90} & \multicolumn{3}{|c|}{0.89} & \multicolumn{3}{|c|}{2.91} \\
\hline \multicolumn{2}{|c|}{ Inorganic fertilizers (s) } & \multicolumn{2}{|c|}{0.56} & \multicolumn{3}{|c|}{1.62} & \multicolumn{3}{|c|}{0.58} & \multicolumn{3}{|c|}{1.63} \\
\hline \multicolumn{2}{|c|}{ Interaction $(\mathrm{m} \mathrm{x} \mathrm{s})$} & \multicolumn{2}{|c|}{1.44} & \multicolumn{3}{|c|}{ NS } & \multicolumn{3}{|c|}{1.45} & \multicolumn{3}{|c|}{4.36} \\
\hline
\end{tabular}


Table.3 Influence of organic and inorganic fertilizers on $\mathrm{N}$ uptake by rice grain and straw in rice-wheat cropping system

\begin{tabular}{|c|c|c|c|c|c|c|c|c|c|c|c|}
\hline \multirow[b]{2}{*}{ Treatments } & \multicolumn{5}{|c|}{$\mathrm{N}$ uptake $\left(\mathrm{kg} \mathrm{ha}^{-1}\right)$ by rice grain } & \multicolumn{6}{|c|}{$\mathrm{N}$ uptake $\left(\mathrm{kg} \mathrm{ha}^{-1}\right)$ by rice straw } \\
\hline & \multicolumn{5}{|c|}{ Organic sources } & \multicolumn{6}{|c|}{ Organic sources } \\
\hline Inorganic fertilizer levels & Dhaincha (GM) & Urd (GL) & FYM Straw & Weedy fallow & Mean & Dhaincha (GM) & Urd (GL) & FYM & Straw & Weedy fallow & Mean \\
\hline Control & 29.88 & 26.19 & 30.0223 .19 & 18.82 & 25.62 & 24.56 & 20.48 & 22.18 & 19.14 & 15.01 & 20.27 \\
\hline $50 \% \mathrm{PK}$ & 31.86 & 27.67 & \begin{tabular}{|l|l|}
33.21 & 24.72 \\
\end{tabular} & 22.33 & 27.96 & 27.09 & 23.96 & 24.81 & 21.63 & 17.44 & 22.99 \\
\hline $50 \% \mathrm{NPK}$ & 50.68 & 40.52 & \begin{tabular}{|l|l|}
49.13 & 36.90 \\
\end{tabular} & 31.24 & 41.69 & 37.36 & 28.34 & 35.29 & 25.35 & 20.79 & 29.43 \\
\hline $100 \% \mathrm{PK}$ & 33.34 & 29.29 & 32.2527 .38 & 24.48 & 29.35 & 28.58 & 24.71 & 28.5 & 20.91 & 16.04 & 23.75 \\
\hline $100 \%$ NPK & 66.65 & 51.08 & 61.4344 .71 & 36.38 & 52.05 & 45.65 & 36.21 & 43.66 & 34.15 & 28.12 & 37.56 \\
\hline Mean & 42.48 & 34.95 & 41.2131 .38 & 26.65 & 35.33 & 32.65 & 26.74 & 30.89 & 24.24 & 19.48 & 26.80 \\
\hline \multicolumn{2}{|l|}{ Sources } & \multicolumn{2}{|c|}{ SEm } & \multicolumn{2}{|c|}{$\mathrm{CD}(p=0.05)$} & \multicolumn{3}{|c|}{ SEm } & \multicolumn{3}{|c|}{$\mathrm{CD}(p=0.05)$} \\
\hline \multicolumn{2}{|l|}{ Organic manures (m) } & \multicolumn{2}{|c|}{0.68} & \multicolumn{2}{|c|}{2.22} & \multicolumn{3}{|c|}{0.57} & \multicolumn{3}{|c|}{1.86} \\
\hline \multicolumn{2}{|l|}{ Inorganic fertilizers (s) } & \multicolumn{2}{|c|}{0.65} & \multicolumn{2}{|l|}{1.86} & \multicolumn{3}{|c|}{0.42} & \multicolumn{3}{|c|}{1.20} \\
\hline \multicolumn{2}{|l|}{ Interaction $(\mathrm{m} \times \mathrm{s})$} & \multicolumn{2}{|c|}{1.47} & \multicolumn{2}{|l|}{4.33} & \multicolumn{3}{|c|}{1.02} & \multicolumn{3}{|c|}{3.03} \\
\hline
\end{tabular}

Table.4 Influence of organic and inorganic fertilizers on P uptake by rice grain and straw in rice-wheat cropping system

\begin{tabular}{|c|c|c|c|c|c|c|c|c|c|c|c|c|}
\hline \multirow{3}{*}{$\begin{array}{l}\text { Treatments } \\
\text { Inorganic fertilizer } \\
\text { levels }\end{array}$} & \multicolumn{6}{|c|}{$\mathrm{P}$ uptake $\left(\mathrm{kg} \mathrm{ha}^{-1}\right)$ by rice grain } & \multicolumn{6}{|c|}{$\mathrm{P}$ uptake $\left(\mathrm{kg} \mathrm{ha}^{-1}\right)$ by rice straw } \\
\hline & \multicolumn{6}{|c|}{ Organic sources } & \multicolumn{6}{|c|}{ Organic sources } \\
\hline & $\begin{array}{l}\text { Dhaincha } \\
\text { (GM) }\end{array}$ & $\begin{array}{l}\text { Urd } \\
(\mathrm{GL})\end{array}$ & FYM & Straw & $\begin{array}{l}\text { Weedy } \\
\text { fallow }\end{array}$ & Mean & $\begin{array}{l}\text { Dhaincha } \\
\text { (GM) }\end{array}$ & $\begin{array}{l}\text { Urd } \\
(\mathrm{GL})\end{array}$ & FYM & Straw & $\begin{array}{l}\text { Weedy } \\
\text { fallow }\end{array}$ & $\begin{array}{l}\text { Mea } \\
\mathrm{n}\end{array}$ \\
\hline Control & 6.16 & 5.33 & 5.90 & 4.81 & 3.61 & 5.16 & 3.90 & 3.22 & 3.55 & 2.98 & 2.71 & 3.27 \\
\hline $50 \% \mathrm{PK}$ & 6.96 & 6.32 & 6.70 & 5.16 & 4.43 & 5.91 & 4.58 & 4.01 & 4.33 & 3.63 & 3.04 & 3.92 \\
\hline $50 \%$ NPK & 9.78 & 7.73 & 9.67 & 6.91 & 5.87 & 7.99 & 7.02 & 5.25 & 6.50 & 4.75 & 3.94 & 5.49 \\
\hline $100 \% \mathrm{PK}$ & 8.39 & 6.98 & 7.96 & 5.68 & 5.23 & 6.85 & 6.02 & 4.84 & 5.81 & 4.56 & 3.73 & 4.99 \\
\hline $100 \%$ NPK & 12.94 & 9.65 & 12.39 & 8.54 & 7.20 & 10.14 & 9.29 & 7.30 & 8.88 & 6.66 & 5.62 & 7.55 \\
\hline Mean & 8.85 & 7.20 & 8.52 & 6.22 & 5.27 & 7.21 & 6.16 & 4.92 & 5.81 & 4.52 & 3.81 & 5.04 \\
\hline \multicolumn{2}{|l|}{ Sources } & \multicolumn{2}{|c|}{ SEm } & \multicolumn{3}{|c|}{$\mathrm{CD}(p=0.05)$} & \multicolumn{3}{|c|}{ SEm } & \multicolumn{3}{|c|}{$\mathrm{CD}(p=0.05)$} \\
\hline \multicolumn{2}{|l|}{ Organic manures (m) } & \multicolumn{2}{|r|}{0.18} & \multicolumn{3}{|c|}{0.64} & \multicolumn{3}{|c|}{0.12} & \multicolumn{3}{|c|}{0.39} \\
\hline \multicolumn{2}{|c|}{ Inorganic fertilizers (s) } & \multicolumn{2}{|r|}{0.13} & \multicolumn{3}{|c|}{0.37} & \multicolumn{3}{|c|}{$\frac{0.09}{021}$} & \multicolumn{3}{|c|}{0.25} \\
\hline \multicolumn{2}{|c|}{ Interaction $(\mathrm{m} \times \mathrm{s})$} & \multicolumn{2}{|r|}{0.32} & \multicolumn{3}{|c|}{0.96} & \multicolumn{3}{|c|}{0.21} & \multicolumn{3}{|c|}{0.64} \\
\hline
\end{tabular}


Table.5 Influence of organic and inorganic fertilizers on K uptake by rice grain and straw in rice-wheat cropping system

\begin{tabular}{|c|c|c|c|c|c|c|c|c|c|c|c|c|}
\hline \multirow[b]{2}{*}{ Treatments } & \multicolumn{6}{|c|}{$\mathrm{K}$ uptake $\left(\mathrm{kg} \mathrm{ha}^{-1}\right)$ by rice grain } & \multicolumn{6}{|c|}{$\mathrm{K}$ uptake $\left(\mathrm{kg} \mathrm{ha}^{-1}\right)$ by rice straw } \\
\hline & \multicolumn{6}{|c|}{ Organic sources } & \multicolumn{6}{|c|}{ Organic sources } \\
\hline Inorganic fertilizer levels & Dhaincha (GM) & Urd (GL) & FYM & Straw & $\mathrm{V}$ Weedy fallow & Mean & Dhaincha (GM) & Urd (GL) & FYM & Straw & Weedy fallow & Mean \\
\hline Control & 8.7 & 7.4 & 8.3 & 6.7 & 5.1 & 7.2 & 55.7 & 40.0 & 52.2 & 45.4 & 38.2 & 46.3 \\
\hline $50 \% \mathrm{PK}$ & 10.0 & 8.1 & 9.6 & 7.5 & 6.3 & 8.3 & 63.4 & 55.2 & 60.0 & 55.0 & 41.8 & 55.1 \\
\hline $50 \%$ NPK & 13.5 & 10.2 & 13.3 & 10.1 & 7.7 & 11.0 & 93.3 & 65.9 & 85.3 & 63.7 & 49.8 & 71.6 \\
\hline $100 \% \mathrm{PK}$ & 11.7 & 9.4 & 11.2 & 9.4 & 7.2 & 9.8 & 80.5 & 62.4 & 76.6 & 62.3 & 48.0 & 65.9 \\
\hline $100 \%$ NPK & 17.2 & 13.6 & 16.8 & 13.0 & 9.2 & 13.9 & 127.7 & 92.9 & 122.0 & 93.7 & 70.8 & 101.4 \\
\hline Mean & 12.2 & 9.7 & 11.8 & 9.3 & 7.1 & 10.0 & 84.1 & 63.3 & 79.2 & 64.0 & 49.7 & 68.1 \\
\hline \multicolumn{2}{|l|}{ Sources } & \multicolumn{3}{|c|}{ SEm } & \multicolumn{2}{|c|}{$\mathrm{CD}(p=0.05)$} & \multicolumn{3}{|c|}{ SEm } & \multicolumn{3}{|c|}{$\mathrm{CD}(p=0.05)$} \\
\hline \multicolumn{2}{|l|}{ Organic manures (m) } & \multicolumn{3}{|c|}{0.29} & \multicolumn{2}{|c|}{0.96} & \multicolumn{3}{|c|}{0.73} & \multicolumn{3}{|c|}{2.37} \\
\hline \multicolumn{2}{|l|}{ Inorganic fertilizers (s) } & \multicolumn{3}{|c|}{0.19} & \multicolumn{2}{|l|}{0.54} & \multicolumn{3}{|c|}{0.84} & \multicolumn{3}{|c|}{2.40} \\
\hline \multicolumn{2}{|l|}{ Interaction $(\mathrm{m} \times \mathrm{s})$} & \multicolumn{3}{|c|}{0.48} & \multicolumn{2}{|l|}{1.46} & \multicolumn{3}{|c|}{1.83} & \multicolumn{3}{|c|}{5.35} \\
\hline
\end{tabular}

Table.6 Influence of organic and inorganic fertilizers on apparent recovery of N, P and K by rice

\begin{tabular}{|c|c|c|c|c|c|c|c|c|c|c|c|c|c|c|c|c|c|c|}
\hline \multirow{3}{*}{\begin{tabular}{|l}
$\begin{array}{l}\text { Treatment } \\
\text { s }\end{array}$ \\
Inorganic \\
fertilizer \\
levels
\end{tabular}} & \multirow{2}{*}{\multicolumn{6}{|c|}{$\frac{\text { Apparent N Recovery }(\%)}{\text { Organic sources }}$}} & \multirow{2}{*}{\multicolumn{6}{|c|}{$\frac{\text { Apparent P Recovery }(\%)}{\text { Organic sources }}$}} & \multicolumn{6}{|c|}{ Apparent K Recovery (\%) } \\
\hline & & & & & & & & & & & & & \multicolumn{6}{|c|}{ Organic sources } \\
\hline & $\begin{array}{l}\text { Dhaincha } \\
(\mathrm{GM})\end{array}$ & $\begin{array}{l}\text { Urd } \\
\text { (GL) }\end{array}$ & FYM & Straw & $\begin{array}{l}\text { Weedy } \\
\text { fallow }\end{array}$ & Mean & $\begin{array}{l}\text { Dhainc } \\
\text { ha } \\
\text { (GM) }\end{array}$ & $\begin{array}{l}\text { Urd } \\
\text { (GL) }\end{array}$ & FYM & Straw & $\begin{array}{l}\text { Weedy } \\
\text { fallow }\end{array}$ & Mean & $\begin{array}{l}\text { Dhaincha } \\
\text { (GM) }\end{array}$ & $\begin{array}{l}\text { Urd } \\
(\mathrm{GL})\end{array}$ & FYM & Straw & $\begin{array}{l}\text { Weedy } \\
\text { fallow }\end{array}$ & Mean \\
\hline $50 \%$ NPK & 48.5 & 28. & 44.0 & 26.5 & 20.5 & 33.6 & 22.5 & 14.1 & 22.4 & 12.9 & 11.7 & 16.7 & 201.7 & 128.4 & 190.6 & 107.9 & 70.9 & 139.9 \\
\hline \begin{tabular}{|l|}
$100 \%$ \\
NPK
\end{tabular} & 42.0 & 27. & 37.0 & 25.5 & 20.2 & 30.5 & 20.3 & 13.7 & 19.7 & 12.4 & 10.8 & 15.4 & 201.3 & 140.1 & 195.8 & 136.2 & 91.6 & 153.0 \\
\hline $50 \% \mathrm{PK}$ & - & - & - & - & - & - & 5.0 & 5.3 & 5.3 & 3.4 & 3.8 & 4.5 & 45.0 & 65.1 & 45.6 & 51.5 & 24.0 & 46.2 \\
\hline $100 \% \mathrm{PK}$ & - & - & - & - & - & - & 7.3 & 5.1 & 7.3 & 4.1 & 4.4 & 5.6 & 69.5 & 53.4 & 68.2 & 48.6 & 29.6 & 53.8 \\
\hline Mean & \begin{tabular}{|l}
45.2 \\
\end{tabular} & 28. & 40.5 & 26.0 & 20.3 & 32.1 & 13.8 & 9.5 & 13.7 & 8.2 & 7.7 & 10.6 & 129.3 & 96.7 & 125.0 & 86.0 & 54.0 & 98.2 \\
\hline \multicolumn{3}{|c|}{ Sources } & \multicolumn{2}{|l|}{ SEm } & \multicolumn{2}{|c|}{$\mathrm{CD}(p=0.05)$} & \multicolumn{3}{|c|}{ SEm } & \multicolumn{3}{|c|}{$\mathrm{CD}(p=0.05)$} & \multicolumn{3}{|c|}{ SEm } & \multicolumn{3}{|c|}{$\mathrm{CD}(p=0.05)$} \\
\hline \multicolumn{3}{|c|}{ Organic manures (m) } & \multicolumn{2}{|l|}{0.77} & \multicolumn{2}{|c|}{2.51} & \multicolumn{3}{|c|}{0.51} & \multicolumn{3}{|c|}{1.64} & \multicolumn{3}{|c|}{2.98} & \multicolumn{3}{|c|}{6.57} \\
\hline \multicolumn{3}{|c|}{ Inorganic fertilizers (s) } & \multicolumn{2}{|l|}{0.49} & \multicolumn{2}{|c|}{1.42} & \multirow{2}{*}{\multicolumn{3}{|c|}{$\begin{array}{l}0.75 \\
157\end{array}$}} & \multicolumn{3}{|c|}{2.13} & \multicolumn{3}{|c|}{1.84} & \multicolumn{3}{|c|}{3.40} \\
\hline \multicolumn{3}{|c|}{ Interaction $(\mathrm{m} \mathrm{x} \mathrm{s})$} & \multicolumn{2}{|l|}{1.36} & \multicolumn{2}{|c|}{3.76} & & & & \multicolumn{3}{|c|}{4.93} & \multicolumn{3}{|c|}{5.23} & & 12.36 & \\
\hline
\end{tabular}


The interaction of organic manures and inorganic fertilizers given to the rice crop significantly influenced the uptake of $\mathrm{P}$ by rice grain and straw. Like grain, the highest $P$ uptake was recorded in straw $\left(9.29 \mathrm{~kg} \mathrm{ha}^{-1}\right)$ in dhaincha (GM) treatment with $100 \%$ NPK combination which was statistically at par to that of FYM treatment with the same levels of inorganic combinations. Thus, it may be inferred that application of inorganic fertilizers along with organic manures increased the P-uptake in rice grain (Mohanty et al., 2013). Kumar et al., (2014) also reported that application of organic and inorganic sources of nutrient in combination (i.e. $125 \% \mathrm{NPK}+5 \mathrm{t} \mathrm{ha}^{-1}$ vermicompost) remarkably increased $\mathrm{P}$ uptake in grains and straws of rice as compared to NPK alone.

\section{$K$ uptake grain and straw}

A view of Table 5 reveal that $\mathrm{K}$ uptake in rice grain and straw varied from 5.11 to $17.19 \mathrm{~kg}$ $\mathrm{ha}^{-1}$ and 38.18 to $127.71 \mathrm{~kg} \mathrm{ha}^{-1}$ respectively as influenced by different organic and inorganic combinations. Weedy fallow treatment of rice resulted into minimum $\mathrm{K}$ uptake both by rice grain $\left(7.09 \mathrm{~kg} \mathrm{ha}^{-1}\right)$ and straw $\left(49.70 \mathrm{~kg} \mathrm{ha}^{-1}\right)$. The maximum $\mathrm{K}$ uptake $\left(12.21 \mathrm{~kg} \mathrm{ha}^{-1}\right)$ in rice grain was observed with GM treatment which was found statistically at par with FYM (11.83 kg ha $\left.{ }^{-1}\right)$. Similarly, GL $\left(9.73 \mathrm{~kg} \mathrm{ha}^{-1}\right)$ and straw $\left(9.32 \mathrm{~kg} \mathrm{ha}^{-1}\right)$ treatments showed no significant variations in $\mathrm{K}$ uptake among themselves. However, significant differences in $\mathrm{K}$ uptake by rice grains were observed in all the above treatments over weedy fallow $\left(7.09 \mathrm{~kg} \mathrm{ha}^{-1}\right)$. In rice straw, highest K-uptake (84.14 $\mathrm{kg} \mathrm{ha}^{-1}$ ) was recorded with GM treatment, which was significantly higher than FYM (79.21 kg ha ${ }^{-1}$ ), straw (64.01 kg ha-1), urd $\left(63.88 \mathrm{~kg} \mathrm{ha}^{-1}\right)$ and weedy fallow (49.70 $\left.\mathrm{kg} \mathrm{ha}^{-1}\right)$ treatments, respectively.

Rice cultivation receiving green manure treatments showed significantly higher uptake of $\mathrm{K}$ over no green manure was also reported by Pattanayak et al., (2001) due to increased availability of $\mathrm{K}$ in GM treated soil.

It was further observed that all the five levels of chemical fertilizers, averaged over organics applied to rice differed significant in their $\mathrm{K}$ contents in grain and straw, among themselves. Thus, $\mathrm{K}$ uptake in rice grain can be presented in the following decreasing order as: $100 \%$ NPK $\left(13.94 \mathrm{~kg} \mathrm{ha}^{-1}\right)>50 \%$ NPK $\left(10.96 \mathrm{~kg} \mathrm{ha}^{-1}\right)>100 \%$ PK $\left(9.75 \mathrm{~kg} \mathrm{ha}^{-1}\right)>$ $50 \%$ PK $\left(8.30 \mathrm{~kg} \mathrm{ha}^{-1}\right)>\operatorname{control}(7.23 \mathrm{~kg} \mathrm{ha}$ $\left.{ }^{1}\right)$. Similar trend was also seen in case of $\mathrm{K}$ uptake in rice straw; where, $\mathrm{K}$-uptake varied in the following decreasing order: $100 \%$ NPK treatment $\left(101.41 \mathrm{~kg} \mathrm{ha}^{-1}\right)>50 \% \mathrm{NPK}(71.57$ $\left.\mathrm{kg} \mathrm{ha}^{-1}\right)>100 \% \mathrm{PK}\left(65.95 \mathrm{~kg} \mathrm{ha}^{-1}\right)>50 \% \mathrm{PK}$ $\left(55.06 \mathrm{~kg} \mathrm{ha}^{-1}\right)>$ control $\left(46.92 \mathrm{~kg} \mathrm{ha}^{-1}\right)$. Liao et al., (2010) also reported that increase in $\mathrm{K}$ uptake with progressive increase in the supply of NPK nutrients in rice-rice cropping system due to higher availability of these nutrients which ultimately resulted in higher biomass yield.

In the present investigation, the interaction effects between organic and inorganic fertilizers on $\mathrm{K}$ uptake in rice grain and straw were found significant. The highest $\mathrm{K}$ uptake value in rice grain $\left(17.19 \mathrm{~kg} \mathrm{ha}^{-1}\right)$ and straw $\left(127.71 \mathrm{~kg} \mathrm{ha}^{-1}\right)$ were recorded under GM + $100 \%$ NPK treatment combination; while, lowest values $\left(5.11 \mathrm{~kg} \mathrm{ha}^{-1}\right)$ in rice grain and $\left(38.18 \mathrm{~kg} \mathrm{ha}^{-1}\right)$ in rice straw were recorded with weedy fallow + control treatment combination. The data further revealed that besides the superiority of $100 \%$ NPK levels + organic combinations on $\mathrm{K}$-uptake in rice grain and straw, 50\% NPK + organic combinations also exhibited superiority over $100 \%$ PK, and control treatments with organic combinations. Thus, the results indicates that conjoint use of organic with the balanced levels of inorganic sources enhanced $\mathrm{K}$ uptake tremendously and significantly over control, in both the cases i.e. rice grain and straw. Several workers (Venkatakrishnan and 
Ravichandran, 2012; Mohanty et al., 2013; Kumar et al., 2014; Dhaliwal et al., 2014) have reported that integration of organic manures with inorganic fertilizers results higher $\mathrm{K}$ availability in soils that leads to increased plant biomass production and consequently higher uptake of this nutrient in grains and straws of rice as compared to recommended NPK fertilizer alone.

\section{Apparent nutrient recovery by rice}

\section{Apparent $\mathbf{N}$ recovery}

Nitrogen use efficiency or apparent $\mathrm{N}$ recovery (ANR) under different treatment combinations (Table 6) varied from $20.2 \%$ at $100 \%$ NPK level with weedy fallow treatment to $48.5 \%$ in $50 \%$ NPK level with GM treatment combination. It was further observed that application of different organic sources helped in increasing the ANR by rice, which was found maximum in GM treatment. However, the data further revealed that higher doses of nitrogen either from organic and inorganic or only inorganic sources resulted in lower ANR in rice indicating physiological efficiency of utilizing applied $\mathrm{N}$ could be satisfied through application of lower dose of inorganic $\mathrm{N}$ fertilizers as well as organics application. These inferences were evinced by the data where ANR was found maximum $(33.62 \%)$ in $50 \%$ NPK treatment while minimum $(30.41 \%)$ was observed in $100 \%$ NPK treatment. The mean ANR can be described in the following order: dhaincha $(45.22 \%)>$ FYM $(40.4 \%)>\operatorname{urd}(28.22 \%)>$ straw $(25.98 \%)>$ weedy fallow $(20.34 \%)$ treatment. These results were also in strict accordance with the findings reported by Dwivedi (1997) in Bihar soils and Mohanty et al., (2013).

\section{Apparent $P$ recovery}

Like ANR, apparent $\mathrm{P}$ recovery (APR) was also found maximum in $50 \%$ NPK treatment in rice (Table 6). On an average, APR by rice ranged between 5.0 to $22.5,5.1$ to $14.1,5.3$ to $22.4,3.4$ to 12.9 and 3.8 to $11.7 \%$ due to GM, GL, FYM, straw and weedy fallow combinations, respectively irrespective of inorganic treatments used. However, the highest mean APR in rice crop was recorded (13.8\%) under GM treatment; while, the lowest mean APR (7.7\%) was observed under weedy fallow treatment. Under sub-plot treatments, the maximum APR (16.7\%) was found at $50 \%$ NPK treatment while minimum (4.5\%) was observed at $50 \%$ PK treatment combination in rice. Higher nutrient $\mathrm{P}$ application by organic and inorganic combinations or only inorganic sources resulted in lower APR. The mean APR in rice were found in the following order: $50 \%$ NPK $(16.72 \%)>100 \%$ NPK $(15.37 \%)>100 \%$ PK $(5.63 \%)>50 \%$ PK $(4.54 \%)$. The results revealed that with increased nutrient uptake by rice, the recovery of applied fertilizer decrease considerably with the addition of organic materials as well as increasing fertility levels. This might be due to the crop need satisfies with the addition of lower dose of nutrients than those of higher rate of application in the present experiment.

\section{Apparent K recovery}

The perusal of data in Table 6 revealed that the apparent $\mathrm{K}$ recovery (AKR) in rice was ranged from 24.0 to $201.70 \%$ due to different treatment combinations irrespective of organic and inorganic treatments compared. The highest mean AKR was recorded as $153.0 \%$ at $100 \%$ NPK level and lowest mean AKR was recorded as $46.2 \%$ at $50 \% \mathrm{PK}$ treatment. Besides this, the application of different organic sources also improved the mean AKR in rice from $54.0 \%$ (weedy fallow) to $86.0 \%, 96.7 \%, 125.0 \%$ and $129.3 \%$ under straw, urd (GL), FYM and dhaincha (GM) treatments, respectively. Contrary to $\mathrm{N}$ and $\mathrm{P}$ use efficiency in rice, $\mathrm{K}$ use efficiency increased along with balanced progressive 
increase in NPK levels indicating that balanced use of NPK fertilizers conjunction with organics resulted in impressive fertilizer use efficiency by rice crop. These results corroborated with the findings of Ghosh et al., (2015). This might be due to the higher uptake of potassium with the application of organics due to more availability of potassium with all the organic sources of nutrients and hence increased efficiency of potassium applied. Similar results have been presented by Sarma and Ramana (1993) and Kumar et al., (2001).

Neither use of organic manures alone nor chemical fertilizers can achieve the sustainability of the yield under the modern intensive farming particularly in rice-wheat cropping system. Under rice-wheat cropping system, the grain and straw yield of rice were considerably influenced by the incorporation of various organic sources like dhaincha (GM), urd (GL), FYM and straw. The maximum grain yield of rice (39.90 q ha-1) was recorded in dhaincha (GM) treatment which was at par with FYM treatment (39.26 $\mathrm{q} \mathrm{ha}^{-1}$ ) but was superior over the other organic sources. Thus, it might be inferred that organics applied to rice crop would definitely displayed a significant positive role on the yield of rice. This impact occurred because of the addition of considerable amounts of organic nutrients which exhibited the higher residual influence as a result of its slow mineralization of organics applied during the experimentation. Similar to the influence of organic sources, the impact of inorganic sources (chemical fertilizers) was also found significant in increasing the grain yield of rice from $27.56 \mathrm{q} \mathrm{ha}^{-1}$ under control to $44.94 \mathrm{q} \mathrm{ha}^{-1}$ under $100 \%$ NPK treatment. Results have also shown that integrated nutrient management increased nutrient uptake as well as the efficiency of nutrient use may be raised by the combined use of organic and inorganic fertilizers. Thus, integrated management of organics and chemical fertilizers in rice found to be more viable for sustaining productivity and improving the efficiency of inorganic fertilizers.

\section{References}

Abrol, I.P., and Gill, M.S. 1994. In: Regional office for Asia and Pacific (FAO) Publication. 11: 172-183.

Acharya, D., and Mandal, S.S. 2010. Effect of integrated nutrient management on the growth, productivity and quality of crops in rice (Oryza sativa L.) - cabbage (Brassica oleracea) - greengram (Vigna radiata) cropping system. Indian Journal of Agronomy, 55(1): 1-5.

Aulakh M.S., M.P.S. Khurana and Singh, D. 2009. Water pollution related to agricultural, industrial and urban activities, and its effects on food chain: Case studies from Punjab. Journal of New Seeds, 10: 112-137.

Aulakh, M.S., 2010. Integrated nutrient management for sustainable crop production, improving crop quality and soil health, and minimizing environmental pollution. $19^{\text {th }}$ World Congress of Soil Science, Soil Solutions for a Changing World, 1-6 August 2010, Brisbane, Australia.

Aulakh, M.S., and Adhya, T.K. 2005. Impact of agricultural activities on emission of greenhouse gases - Indian perspective. pp. 319-335. In: Proceedings of the International Conference on Soil, Water and Environmental Quality - Issues and Strategies, Indian Society of Soil Science, New Delhi.

Brahmachari, K., S.R. Choudhury, S. Karmakar, S. Dutta and Ghosh, P. 2011. Sustainable nutrient management in rice (Oryza sativa) - Paira Chickling Pea (Lathyrus sativus) - Green Gram (Vigna radiata) sequence to improve total productivity of land under coastal zone 
of West Bengal. Rajshahi University Journal of Environmental Science, 1: 51-61.

Das, A., R.P. Sharma, N. Chattopadhyaya and Rakshit, R. 2014. Yield trends and nutrient budgeting under a long-term (28 years) nutrient management in ricewheat cropping system under subtropical climatic condition. Plant Soil and Environment, 60(8): 351-357.

Dass A., S. Sudhishri and Lenka, N.K. 2009. Integrated nutrient management for upland rice in Eastern Ghats of Orissa. Oryza, 46(3): 220-226.

Dhaliwal, J.K., G.S. Saroa and Dhaliwal, S.S. 2014. Effect of nutrient management techniques on phosphorus availability in basmati-wheat system. International Journal of Science, Environment and Technology, 3(4): 1602-1608.

Dixit, K.G., and Gupta, B.R. 2000. Effect of Farm yard manure, chemical and biofertilizers on yield and quality of rice and soil properties. Journal of the Indian Society of Soil Science, 48(4): 773-780.

Dobermann, A., 2007. Nutrient use efficiency - measurement and management. pp. 128. In: IFA International Workshop on Fertilizer Best Management Practices, Brussels, Belgium.

Dubey, S.K., R.S. Sharma and Viswakarma, S.K. 1997. Integrated nutrient management for sustainable productivity of important cropping systems in Madhya Pradesh. Indian Journal of Agronomy, 42: 13-18.

Dwivedi, D.K., 1997. Integrated nutrient management for sustainable production under rice wheat cropping system. Ph. $\mathrm{D}$ thesis in Agronomy, Rajendra Agricultural University, Pusa, Samastipur, Bihar, India.

Ghosh, B.N., R.J. Singh and Mishra, P.K. 2015. Soil and input management options for increasing nutrient use efficiency. In: Nutrient Use Efficiency: from Basics to Advances, (eds. A Rakshit et al.,) DOI 10.1007/978-81322-2169-22, Springer, India.

Jackson, M.L., 1973. Soil chemical analysis. New Delhi: Prentice Hall of India.

Jaga, P.K., 2013. Effect of integrated nutrient management on wheat - a review. Innovare Journal of Agricultural Sciences, 1(1): 185-191.

Jha, M.N., S.K. Chaurasia and Bharti, R.C. 2013. Effect of integrated nutrient management on rice yield, soil nutrient profile and cyanobacterial nitrogenase activity under rice-wheat cropping system. Communications in Soil Science and Plant Analysis, 44(3): 1961-1975.

Karmakar, S., S. Prakash, R. Kumar, B.K. Agrawal, D. Prasad and Kumar, R. 2011. Effect of green manuring and biofertilizers on rice production. Oryza, 48(4): 339-342.

Kumar, A., R.N. Meena, L. Yadav and Gilotia, Y.K. 2014. Effect of organic and inorganic sources of nutrient on yield, yield attributes and nutrient uptake of rice $\mathrm{Cv}$. PRH-10. The Bioscan, 9(2): 595-597.

Kumar, N., L.P. Verma, R. Singh and Prasad, K. 2001. Soil properties, nutrients uptake and productivity of rice under integrated nutrient management system. Annals of Plant and Soil research, 3: 5457.

Kumar, V., R.K. Prasad, S.N. Suman and Tiwari, S. 2011. Integrated nutrient management for better soil fertility and rice productivity. Oryza, 48(4): 335338.

Kumari, N., A.K. Singh, S.K. Pal and Thakur, R. 2010. Effect of organic nutrient management on yield, nutrient uptake and nutrient balance sheet in scented rice (Oryza sativa). Indian Journal of Agronomy, 55(3): 220-223.

Ladha, J.K., D. Dawe, H. Pathak, A.T. Padre, 
R.L. Yadav, B. Singh, Y. Singh, Y. Singh, P. Singh, A.L. Kundu, R. Sakal, N. Ram, A.P. Regmi, S.K. Gami, A.L. Bhandari, R. Amin, C.R. Yadav, E.M. Bhattarai, S. Das, H.P. Aggarwal, R.K. Gupta and Hobbs, P.R. 2003. How extensive are yield declines in longterm rice-wheat experiments in Asia? Field Crops Research, 81: 159-180.

Ladha, J.K., Fischer, M. Hossain, P.R. Hobbs and Hardy, B. 2000. Improving the productivity and sustainability of ricewheat systems of the Indo-Gangetic Plains: A synthesis of NARS-IRRI partnership research. Disc. Paper No. 40. International Rice Research Institute, Philippines.

Ladha, J.K., H. Pathak, T.J. Krupnik, J. Six and Kessel, C.V. 2005. Efficiency of fertilizer nitrogen in cereal production: retrospects and prospects. Advances in Agronomy, 87: 85-156.

Li, Z., M. Liu, X. Wu, F. Han and Zhang, T. 2010. Effects of long-term chemical fertilization and organic amendments on dynamics of soil organic $\mathrm{C}$ and total $\mathrm{N}$ in paddy soil derived from barren land in subtropical China. Soil and Tillage Research, 106: 268-274.

Liao, Y., S. Zheng, Y. Lu, Z. Yang, J. Nie and Xie, J. 2010. Long-term effect of fertilizer application on rice yield, potassium uptake in plants, and potassium balance in double rice cropping system. Frontiers of agriculture in China, 4(4): 406-415.

Mehdi, S.M., M. Sarfraz, S.T. Abbas, G. Shabbir and Akhtar, A. 2011. Integrated nutrient management for rice-wheat cropping system in a recently reclaimed soil. Soil and Environment, 30(1): 3644.

Mitran, T., P.K. Mani, N. Basak, D. Mazumder and Roy, M. 2015. Longterm manuring and fertilization influence soil inorganic phosphorus transformation vis-a-vis rice yield in a rice-wheat cropping system. Archives of Agronomy and Soil Science, DOI: 10.1080/03650340.2015.1036747.

Modgal, S.C., Y. Singh and Gupta, P.C. 1995. Nutrient management in rice-wheat cropping system. Fertilizer News, 40: 49-54.

Mohanty, M., S.S. Nanda and Barik, A.K. 2013. Effect of integrated nutrient management on growth, yield, nutrient uptake and economics of wet season rice (Oryza sativa) in Odisha. Indian Journal of Agricultural Sciences, 83(6): 599-604.

Patel, N.M., R.P.S. Ahlawat and Ardeshna, R.B. 1997. Direct and residual effect of phosphorus in rice-wheat sequence under south Gujrat condition. Indian Journal of Agronomy, 42: 18-22.

Patro, H., D. Dash, D. Parida, P.K. Panda, A. Kumar, R.C. Tiwari and Shahid, M. 2011. Effect of organic and inorganic sources of nitrogen on yield attributes, grain yield and straw yield of rice (Oryza Sativa). International Journal of Pharma and Bio Sciences, 2(2): 1-8.

Pattanayak, S.K., K.N. Mishra and Nayak, R.K. 2001. Evaluation of green manure crops fertilized with various phosphorus sources and their effect on subsequent rice crop. Journal of the Indian Society of Soil Science, 49: 285-291.

Prasad, B., J. Prasad and Prasad, R. 1995. Nutrient management for sustainable rice and wheat production in calcareous soil amended with green manures, organic manures and zinc. Fertilizer News, 40: 39-45.

Rahman, F., A.T.M.S. Hossain, P.K. Saha and Miah, M.A.M. 2009. Effect of integrated use of organic manures and chemical fertilizers on yield, nutrient uptake and nutrient balance in the bush bean - T. aus - T. aman cropping 
pattern. Bangladesh Journal of Agricultural Research, 34(1): 157-164. Ramalakshmi, C.S., P.C. Rao, T. Sreelatha, M. Mahadevi, G. Padmaja, P.V. Rao and Sireesha, A. 2012. Nitrogen use efficiency and production efficiency of rice under rice-pulse cropping system with integrated nutrient management. Journal of Rice Research, 5(1\&2): 4251.

Sarma, P.S., and Ramana, S. 1993. Response of sorghum to nitrogen and potassium in Alfisol. Journal of Potassium Research, 9: 171-175.

Sharma, R.C., and Banik, P. 2012. Effect of integrated nutrient management on baby corn-rice cropping system: economic yield, system productivity, nutrient-use efficiency and soil nutrient balance. Indian Journal of Agricultural Sciences, 82(3): 28-32.

Singh, R.P., S.V. Subiah and Pillai, K.G. 1994. Summary of rice-wheat cropping system trials being pursued by the DRRW. Workshop at Punjab Agricultural University, Ludhiana, India (30 ${ }^{\text {th }}$ Aug. to $2^{\text {nd }}$ September, 1994).

Srinivasarao, C., B.K. Ramachandrappa, V.S. Jakkula, S. Kundu, B. Venkateswarlu, A.L. Pharande, V.R. Manideep, R.P. Naik and Venkanna, K. 2014. Nutrient balance after thirteen years of organic and chemical nutrient management and yield sustainability of groundnut- finger millet rotation in rainfed Alfisols of semi-arid India. Journal of the Indian Society of Soil Science, 62(3): 235-247.

Udayasoorian, C., K.N. Govindaswamy and Subbian, P. 1997. Effect of Trichoderma viridae additional nitrogen and farm yard manures on the productivity and sustainability of rice (Oryza sativa) rice groundnut (Arachis hypogea) system. Indian Journal of Agronomy, 42: 1-4.

Venkatakrishnan, D., and Ravichandran, M. 2012. Effect of integrated nutrient management on sugarcane yield and soil fertility on an UlticHaplustalf. Journal of the Indian Society of Soil Science, 60: 74-78.

Yadav, G.S., M. Datta, S. Basu, C. Debnath and Sarkar, P.K. 2013. Growth and productivity of lowland rice (Oryza sativa) as influenced by substitution of nitrogenous fertilizer by organic sources. Indian Journal of Agricultural Sciences, 83(10): 1038-1042.

Yang, C., L. Yang, Y. Yang and Ouyang, Z. 2004. Rice root growth and nutrient uptake as influenced by organic manure in continuously and alternately flooded paddy soils. Agricultural Water Management, 70: 67-81.

\section{How to cite this article:}

Sunil Kumar, Bholanath Saha, Sushanta Saha, Anupam Das, Parthendu Poddar and Manikant Prabhakar. 2017. Integrated Nutrient Management for Enhanced Yield, Nutrients Uptake and their Use Efficiency in Rice under Intensive Rice-Wheat Cropping System. Int.J.Curr.Microbiol.App.Sci. 6(10): 1958-1972. doi: https://doi.org/10.20546/ijcmas.2017.610.236 